\title{
The green-house gas (GHG) emission's reduction mechanisms for biofuels in the European legislation ${ }^{\text {th }}$
}

\author{
Philippe Dusser ${ }^{*}$ a \\ Études Économiques - AVRIL, Paris, France
}

Received 13 June 2019 - Accepted 2 October 2019

\begin{abstract}
GHG reductions are a major focus of the EU policy. Several regulations have been set in order to meet the EU commitments under the Paris Agreement with an overall reduction of 40\% from 1990 level. For the transport sector which is responsible for around $20 \%$ of the total GHG emissions, the GHG reductions obligations have been translated by i) reinforced $\mathrm{GHG}$ reduction thresholds for biofuels into the recast Renewable Energy Directive RED II; ii) an ambitious target of 30\% GHG emission reduction target from 2005 level in the Effort Sharing Regulation (ESR) common to "non-ETS sector" (not covered by the Emission Trading System-ETS) as agriculture, building, waste... and transport. Furthermore, other EU regulations directed to Cars, Vans as well as Heavy Duty Vehicles set GHG emission reduction targets for new vehicle up to 2030. Finally, in its communication "A Clean Planet for All" the EU Commission describes A Strategy for 2050 to achieve a carbon neutral economy. This article addresses also the case of the German "GHG quota" which is a national support system for biofuels and as such is parallel to the European obligations stemming from the RED II renewable energy mandates that are to be met by Germany.
\end{abstract}

Keywords: GHG reductions / sustainability criteria / Renewable Energy Directive / RED II / German GHG quota system / carbon footprint / Fuel Quality Directive / Effort Sharing Regulation (ESR) / clean planet for all / carbon neutrality

\begin{abstract}
Résumé - Les mécanismes de réduction des émissions de gaz vert (GES) pour les biocarburants dans la législation européenne. Les réductions de GES sont un objectif majeur de la politique de l'UE. Plusieurs réglementations ont été fixées afin de respecter les engagements de l'UE dans le cadre de l'Accord de Paris avec une réduction globale de $40 \%$ par rapport au niveau de 1990. Pour le secteur des transports qui est responsable d'environ $20 \%$ des émissions totales de GES, les obligations de réduction des GES ont été traduites par i) des seuils renforcés de réduction des GES pour les biocarburants dans la refonte de la Directive sur les énergies renouvelables RED II ; ii) un objectif ambitieux de réduction des émissions de GES de $30 \%$ par rapport au niveau de 2005 dans le réglement sur la répartition des efforts (ESR -Effort Sharing Regulation) commun au «secteur non-ETS» (non couvert par le système d'échange de quotas d'émission-ETS) comme l'agriculture, la construction, les déchets... transport. En outre, d'autres réglementations de l'UE visant les voitures, les fourgonnettes ainsi que les véhicules lourds ont fixé des objectifs de réduction des émissions de GES pour les véhicules neufs jusqu'en 2030. Enfin, dans sa communication «Une planète propre pour tous », la Commission européenne décrit une stratégie pour 2050 visant à parvenir à une économie neutre en carbone. Cet article aborde également le cas du « quota de GES » allemand, qui est un système national de soutien aux biocarburants et qui, à ce titre, est parallèle aux obligations européennes qui doivent être respectés par l'Allemagne au titre des mandats RED II en matière d'énergie renouvelable.
\end{abstract}

Mots clés : réductions de GES / critères de durabilité / Directive sur les énergies renouvelables / RED II / système allemand de quotas de GES / empreinte carbone / Directive sur la qualité des carburants / réglement sur la répartition de l'effort / Effort Sharing Regulation (ESR) / une planète propre pour tous / neutralité carbone

\footnotetext{
Contribution to the Topical Issue "Biodiesel / Biodiesel".

*Correspondence: philippe.dusser@outlook.com

${ }^{a}$ Ex-directeur des Études Économiques-AVRIL, Paris, France.
} 
Table 1. Greenhouse gas savings thresholds in RED II.

\begin{tabular}{llll}
\hline Plant operation start date & Transport biofuels (\%) & $\begin{array}{l}\text { Transport renewable fuels } \\
\text { of non-biological origin (\%) }\end{array}$ & $\begin{array}{c}\text { Electricity, heating } \\
\text { and cooling (\%) }\end{array}$ \\
\hline Before October 2015 & 50 & - & - \\
After October 2015 & 60 & - & - \\
After January 2021 & 65 & 70 & 70 \\
After January 2026 & 65 & 70 & 80 \\
\hline
\end{tabular}

\section{RED Il's GHG thresholds guarantee a minimum level of GHG reduction from eligible biofuels}

Biofuels have to meet a minimum GHG reduction threshold to be eligible and be accounted for in the energy blending mandates fixed by the Renewable Energy Directive (RED I and RED II) as well as toward the 6\% GHG reduction target in fuels fixed for 2020 by the Fuel Quality Directive (FQD) (Fuel Quality Directive, 2009). The reduction is calculated by comparing the GHG emissions linked to the production of the biofuel (from the field to the pump), to a reference for a fossil fuel.

GHG reduction thresholds are part of the "sustainability criteria" required from biofuels along with other environmental criteria (no feedstock coming from grassland, forest land or highly biodiverse land).

The GHG reduction threshold has been raised from an initial $35 \%$ in 2010 , up to $50 \%$ for investments done before 2015 , and $60 \%$ for those after 2015 ; it is fixed at $65 \%$ for the investments that will be done after 2021 (Tab. 1).

\section{The German "GHG quota" system - A national biofuel support system based on GHG reduction}

In 2015, the German Government introduced a new "GHG quota" support system for the renewable energy in transport by which fuel retailers have an obligation to decarbonize the fuel they put on the market.

This "GHG quota" system had been previously scheduled by a 2006 national legislation and planned to replace a blending obligation of 6.25\% "energy quota" in 2015 (German Green-house Gas Quota, 2006). As planned, the German green-house gas reduction commitment (on fuel suppliers) started in 2015 at a $3.5 \%$, increased to $4 \%$ in 2017 ; it will be set at $6 \%$ from 2020 on.

This change created a certain disruption in the European biofuels market context, where all other countries had maintained the previous support system based on volume or energy blending obligation - as in France the so called "TGAP system".

As a matter of fact, EU's incentives to GHG savings in transport biofuels during the period 2010-2020, are based on 2 different, although harmonized, Directives:
- the RED I (Renewable Energy Directive) which sets an obligation on Member States to incorporate $10 \%$ of renewables into transport, with a minimum GHG saving eligibility threshold;

- the FQD (Fuel Quality Directive), which requires fuel retailers to reduce the carbon footprint of fuels by $6 \%$ by 2020 (Fuel Quality Directive, 2009).

In choosing to change their national support system, the German authorities expected its EU-wide generalization after 2020 in the framework of the recast of the EU renewable policy for the next 2020-2030 decade. But as most other countries kept their own national blending obligation system, the EU Commission didn't reconduct the FQD (Fuel Quality Directive, 2009) for the post 2020. The Commission proposed a recast of the sole Renewable Energy Directive with higher blending obligations (14\% instead of $10 \%$-but a $7 \%$ cap on crop-based biofuels), higher GHG savings eligibility thresholds, and incentives to move toward low-emission biofuels, while for the FQD side Member States are only required not to back from the $6 \%$ GHG reduction in fuel due for 2020 .

Nevertheless, RED II offers the flexibility to Member States to choose the system by which they support the renewable energy in transport. Hence the German "GHG quota system" will continue after 2020, but in addition to the national German GHG Quota, German fuel retailers will be required to meet the 14\% RED II blending obligation of Renewable energy in transport.

Consequences of the introduction of the German "GHG quota":

- a segmentation of the EU biofuels market;

- a decrease of crop-based biofuels consumption in Germany due to their lower GHG emission reductions compared to biofuels made from waste and residues;

- the development of a trans-border trade of biofuels... and paper certificates.

As all other countries were keeping an energy volume blending system of support, the German "GHG Quota system" has introduced a segmentation in the biofuels market and fueled trans-border movements whereby the different feedstocks are traded and directed wherever they get the higher reward from their respective characteristics - energy content or GHG savings - (Fig. 1). 


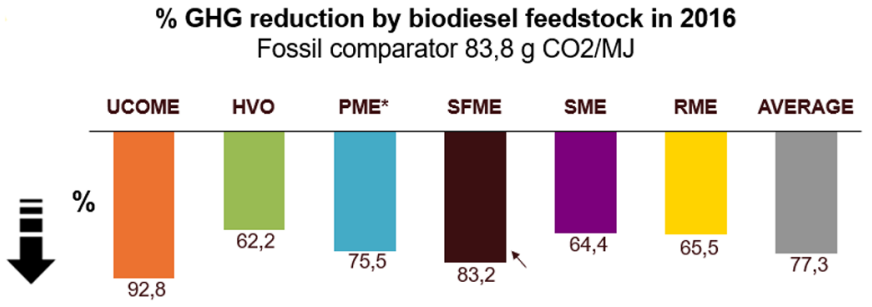

Fig. 1. UCOME: used cooking oil methyl ester; HVO: hydrotreated vegetable oil (generally from Palm oil); *PME: palm with "methane capture"; SFME: sunflower methyl ester; SME: soybean methyl ester; RME: rapeseed methyl ester.

Nota: The fossil comparator will change from 83.9 to $94 \mathrm{~g} \mathrm{CO} 2 \mathrm{eq}$ in 2020 with RED II implementation.

Therefore, in Germany, crop-based biofuels consumption decreased dramatically (Fig. 2) replaced by waste and residues (UCOME) with much higher GHG savings (around 90\%) than crop-based biodiesel (around 65\%). This situation leads to surprising prices differences between feedstock where waste (Used Cooking oil) is priced at a premium over crude vegetable oil.

As Germany imports and concentrates the low GHG biofuels availabilities like UCO, higher GHG biofuels are directed to other countries (like France). These exchanges are being made easier by the "mass balance" system whereby there is no need of actual physical movements which may be replaced by exchanges of paper certificates.

\section{The "Effort Sharing Reduction": global GHG reduction targets involving the transport sector could support an increased crop-biofuel demand for the future}

Member States in October 2014 agreed to set a binding economy-wide domestic emission reductions target of at least $40 \%$ by 2030 compared to 1990 . This target has been split between a reduction for sectors (mainly industry) included in the Emission Trading System (ETS) and the non-ETS sectors amounting to $43 \%$ and $30 \%$ respectively by 2030 compared to 2005.

The Transport sector together with others like Buildings and Agriculture is part of the non-ETS sectors which in total account for almost $60 \%$ of total domestic EU emissions (Fig. 3).

The "Effort Sharing Regulation" (ESR) adopted in May 2018 translates this commitment into binding annual greenhouse gas emission reduction targets for each Member State for the period 2021-2030. The countries national 2030 targets range from 0\% (Bulgaria) to $40 \%$ (LuxemburgSweden) compared to 2005 levels depending on their respective GDP and other considerations.

As the transport sector makes up to one third of the nonETS sectors, it may be questioned whether RED II obligations will ensure enough GHG saving to meet the global ESR target.
As the RED II provides "multipliers" to support the profitability of second and third generation biofuels (e.g. Waste and residues counting double; on-road electricity counting 4 times), the RED II objectives may be reached with "theoretical GHG savings" much lower than the actual ones. This is not the case for the ESR obligations, where only actual GHG savings are accounted for. As ESR sectors others than Agriculture and Transport have their own difficulties to reach their obligations, crop-biofuels could prove to be the only solution to fulfill the ESR's $30 \%$ GHG reduction in 2030 , and the pressure could happen soon enough as the trajectory of the annual reduction will be linear.

\section{Other GHG regulations: post-2020 GHG reduction targets for vehicles ${ }^{1}$}

\subsection{GHG standards for cars and vans}

Agreed in December 2018 and published in April 2019, this regulation requires $(\mathrm{CO} 2$ standards for cars and vans, 2019):

- 37.5\% GHG emission reduction target for new cars by 2030 and;

- $31 \%$ GHG reduction for new vans;

- an interim target of 15\% GHG reduction for both in 2025 .

For Heavy Duty Vehicles a similar agreement was reached in April 2019 requiring (CO2 standards for heavy duty vehicles, 2019):

- 30\% reduction from 2019 baseline in 2030;

$-15 \%$ reduction by 2025 .

\section{EU 2050 strategy for decarbonization of the European economy "A Clean Planet for All”' (A Clean Planet for All, 2018)}

This Communication from the Commission answering a request by the Heads of State in March 2018 was published in November 2018. It gives a vision on the long-term strategy to meet the Paris Agreement's goal which would require for the EU to achieve a carbon-neutral economy by 2050 .

It doesn't set any specific targets, but affirms a vision and explore options for all sectors,

The power sector will become a central element for the transformation of other economic sectors. All pathways converge on one central element: power generation should be fully decarbonised by 2050 . More than $80 \%$ of the EU's electricity would be produced by renewable energy sources.

For the transport sector the communication recognizes that it will continue to rely on fossil fuels, and that efforts must be made under an integrated approach (vehicle efficiency, use of zero emission fuels, changes in mobility modes).

\footnotetext{
${ }^{1}$ It must be noted nevertheless that these objectives related to the vehicles constitute incentives for the electrification and not for biofuels. As the emissions targeted in this case are those observed at the exhaust pipe, and that combustion of a biofuel is similar as a that of a fossil fuel.
} 
Domestic consumption 2014-2018 ${ }^{1}$ Counted towards quota ${ }^{2}$

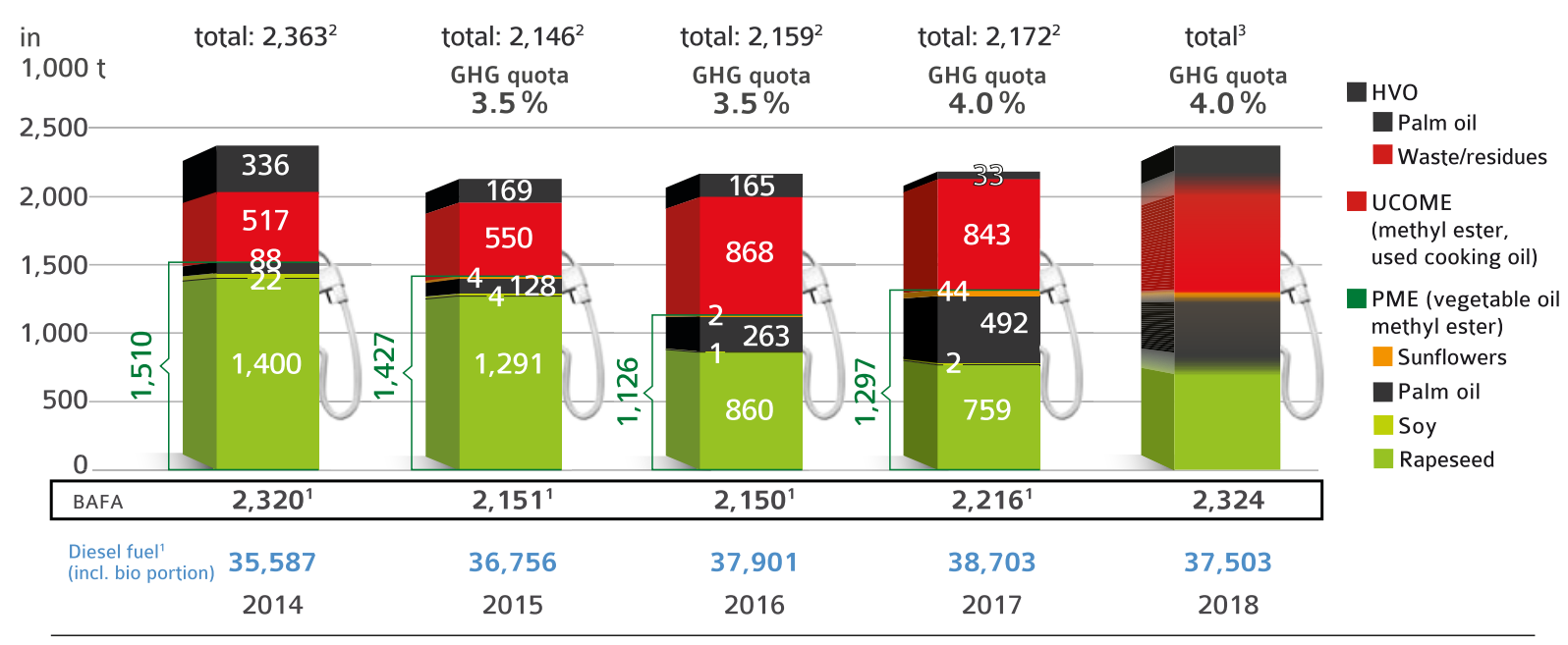

Sources: 'BAFA, ${ }^{2}$ BLE, ${ }^{3}$ BLE evaluation report 2018 expected for October 2019

Fig. 2. Feedstocks use in biodiesel.

From UFOP_Report_on_Global_Market_Supply_18-19.

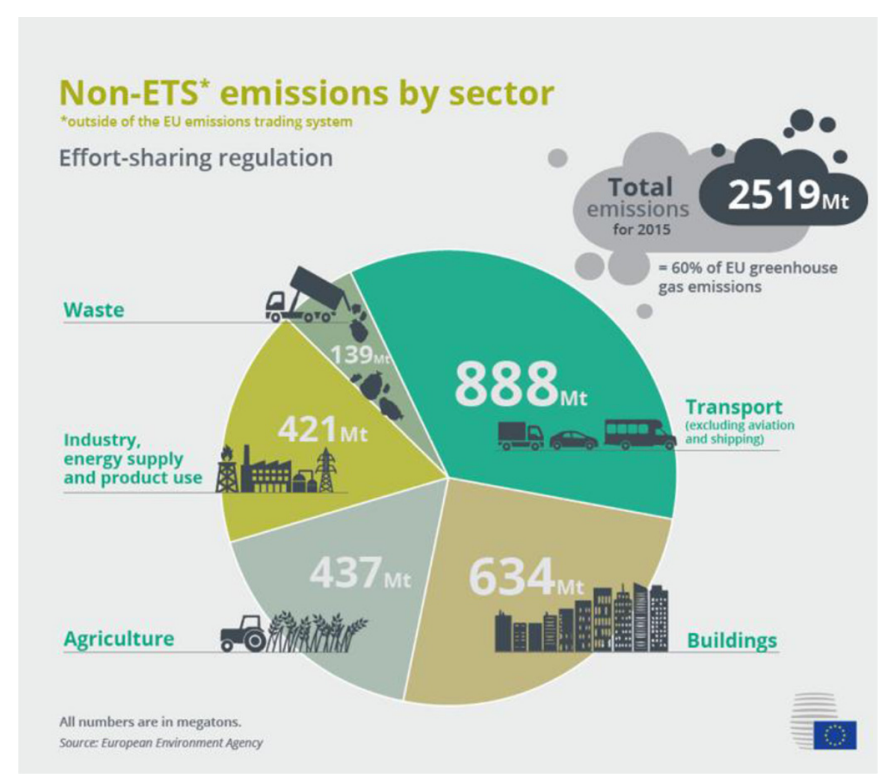

Fig. 3. GHG emissions by sector.

\section{References}

A Clean Planet for All. 2018. 28/11/2018-COM (2018) 773-A clean planet for all-A European strategic long-term vision for a prosperous, modern, competitive and climate neutral economy. Available from https://eur-lex.europa.eu/legal-content/EN/TXT/? uri=CELEX:52018DC0773.

CO2 standards for cars and vans. 2019. Regulation (EU) 2019/631 of the European Parliament and of the Council of 17 April 2019 setting $\mathrm{CO} 2$ emission performance standards for new passenger cars and for new light commercial vehicles, and repealing Regulations (EC) No 443/2009 and (EU) No 510/2011
(Text with EEA relevance). Available from http://data.europa. eu/eli/reg/2019/631/oj.

CO2 standards for heavy duty vehicles. 2019. Regulation (EU) 2019/

1242 of the European Parliament and of the Council of 20 June 2019 setting CO2 emission performance standards for new heavyduty vehicles and amending Regulations (EC) No 595/2009 and (EU) 2018/956 of the European Parliament and of the Council and Council Directive 96/53/EC. Available from http://data.europa. eu/eli/reg/2019/1242/oj.

Effort Sharing Regulation-ESR. 2016. Proposal for a Regulation of the European Parliament and of the Council on binding annual greenhouse gas emission reductions by Member States from 2021 to 2030 for a resilient Energy Union and to meet commitments under the Paris Agreement and amending Regulation No 525/ 2013 of the European Parliament and the Council on a mechanism for monitoring and reporting greenhouse gas emissions and other information relevant to climate change. COM/2016/0482 final 2016/0231 (COD). Available from https://eur-lex.europa.eu/ legal-content/EN/TXT/?uri=CELEX:52016PC0482.

Fuel Quality Directive-FQD. 2009. Directive 2009/30/EC of the European Parliament and of the Council of 23 April 2009 amending Directive 98/70/EC as regards the specification of petrol, diesel and gas-oil and introducing a mechanism to monitor and reduce greenhouse gas emissions and amending Council Directive 1999/32/EC as regards the specification of fuel used by inland waterway vessels and repealing Directive 93/12/EEC (Text with EEA relevance). Available from https://eur-lex.europa.eu/ legal-content/EN/TXT/?uri=CELEX:32009L0030.

German Green-house Gas Quota. 2006. Gesetz zur Einführung einer Biokraftstoffquote durchÄnderung des Bundes-Immissionsschutzgesetzes undzur Änderung energie- und stromsteuerrechtlicher Vorschriften(Biokraftstoffquotengesetz-BioKraftQuG) 1)2) Vom 18. Dezember 2006. Available from https://www. bgbl.de/xaver/bgbl/start.xav?startbk=Bundesanzei ger BGBl\&bk=Bundesanzeiger B GB1\&start $=/ / * \%$ 5B@attr_id=\%27bgbl106s3180.pdf\% $27 \% 5 \mathrm{D} \#$ bgbl_\%2F 
$\% 2 \mathrm{~F} * \% 5 \mathrm{~B} \% 40$ attr_id \%3D\%27bgbl106s3180.pdf\%27\% 5D $1568645144768^{-}$.

RED II. 2018. Directive (EU) 2018/2001 of the European Parliament and of the Council of 11 December 2018 on the promotion of the use of energy from renewable source. Available from https://eurlex.europa.eu/legal-content/EN/TXT/?uri=uriserv:OJ. L .2018.328.01.0082.01.ENG.
The Renewable Energy Directive (2009/28/EC-RED I). 2009. Directive 2009/28/EC of the European Parliament and of the Council of 23 April 2009 on the promotion of the use of energy from renewable sources and amending and subsequently repealing Directives 2001/77/EC and 2003/30/EC (Text with EEA relevance). Available from https://eur-lex.europa.eu/LexUr iServ/LexUriServ.do?uri=OJ:L:2009:140:0016:0062:en:PDF.

Cite this article as: Dusser P. 2019. The green-house gas (GHG) emission's reduction mechanisms for biofuels in the European legislation. OCL 26: 45 . 